\title{
Lactic fermentation enhances the antioxidant activity of gold kiwifruit
}

\author{
Ji-yeon Ryu ${ }^{1}$, Hyun Jeong Park ${ }^{1}$, Jeong Yong Moon ${ }^{2}$, Chan-Shick Kim ${ }^{1}$, \\ Somi Kim Cho ${ }^{1,2 *}$ \\ ${ }^{1}$ School of Biomaterials Sciences and Technology, College of Applied Life Sciences, SARI, Jeju National University, \\ Jeju 63243, Korea \\ ${ }^{2}$ Subtropical/Tropical Organism Gene Bank, Jeju National University, Jeju 63243, Korea
}

\section{유산균 발효에 의한 골드키위 발효물의 항산화 효능 증진}

\author{
류지연 ${ }^{1} \cdot$ 박현정 $^{1}$ - 문정 용 $^{2}$ - 김찬식 ${ }^{1}$. 김소미 ${ }^{1,2 *}$ \\ ${ }^{1}$ 제주대학교 바이오소재공학과, ${ }^{2}$ 아열대 · 열대생물유전자은행센터
}

\begin{abstract}
Gold kiwifruit was fermented with Lactobacillus plantarum CK10 derived from kimchi and the fermented products were extracted with ethanol at various fermentation time-points The bacterial cellular density, total titratable acidity, total polyphenol content (TPC), and total flavonoid content (TFC) increased during fermentation, while pH values and total soluble solids decreased. Levels of TPC and TFC were highest after five days, at $1.21 \pm 0.13 \mathrm{mg}$ GAE$/ \mathrm{g}$ dry weight and $0.36 \pm 0.04 \mathrm{mg} \mathrm{RE} / \mathrm{g}$ dry weight, respectively. The antioxidant activities of the fermented gold kiwifruit were analyzed using $\mathrm{Fe}^{2+}$ chelating activity, 2,2-diphenyl-1-picrylhydrazyl (DPPH)-, and 2,2'-azino-bis(3ethylbenzothiazoline-6-sulphonic acid) (ABTS)- radical scavenging activities, and superoxide dismutase (SOD)-like activity. The $\mathrm{Fe}^{2+}$ chelating activity of gold kiwifruit $(125-500 \mu \mathrm{g} / \mathrm{mL})$ peaked after five days of fermentation at 38.40-78.47\%. The DPPH radical- scavenging activity and SOD-like activity were somewhat higher after seven days of fermentation (36.01-86.81\% and $54.79-93.83 \%$ at $2.5-10.0 \mathrm{mg} / \mathrm{mL}$ concentration of samples, respectively). On the other hand, the ABTS radical- scavenging activity of fermented gold kiwifruit was similar to that of the non-fermented form. The polyphenol and flavonoid contents were significantly correlated with the antioxidant activity. In conclusion, our results suggest that TPC, TFC, and antioxidant activity were increased after five and seven days of fermentation, respectively. Therefore, fermented gold kiwifruit with its increased antioxidant activity could be useful in the development of functional foods.
\end{abstract}

Key words : antioxidant, chemical characteristics, fermentation, gold kiwifruit, Lactobacillus plantarum

\begin{abstract}
서 론
키위는 다래나무과(Acinidiaceae) 다래나무속(Actinidia) 에 속하는 자웅이주의 넝쿨성 낙엽과수로 주로 온대지역에 서 자라며, 전 세계적으로 64종의 품종이 있다. 경제성이 있는 품종으로서 참다래로 알려진 Hayward 품종과 제스프
\end{abstract}

*Corresponding author. E-mail : phd.kim.somi@gmail.com Phone : 82-64-754-3348, Fax : 82-64-756-3351

Received 31 January 2018; Revised 19 March 2018; Accepted 27 March 2018.

Copyright (c) The Korean Society of Food Preservation. All rights reserved.
리골드키위로 알려진 Hort16A 품종이 전 세계적으로 상용 화되고 있다. 국내에서도 다양한 품종들이 개발되어 주로 남해안 일대와 제주도에서 재배되고 있는데 $(1,2)$, 이 중에 서 '한라골드'는 국내에서 육성되고 보급된 골드키위 품종 으로서 과육색은 밝은 황색을 나타내며 과즙이 많고 부드럽 다. 또한, 나무 가지에 털이 없으며 당도가 높은 특성을 지니고 있다(3). 키위는 식품의 맛, 향미뿐만 아니라 다양한 생리활성에 기여한다고 알려진 페놀성 화합물을 함유하고 있으며, 비타민 $\mathrm{C}$ 가 풍부하고, 클로로필, 카로티노이드와 같은 건강에 유익한 다양한 생리활성물질을 함유하고 있다 (4). 키위의 경우 특히 미네랄 함량이 사과, 포도 등과 비교 하여 2-3배 정도 높다고 알려져 있으며, 퀴닌산, 말산, 시트 
르산 등 유기산이 존재하여 키위의 특유의 풍미를 가진다고 알려져 있다(1). 이러한 키위와 관련한 연구로는 화학성분 과 항산화 활성(2), 신경세포 보호 효과(4), tyrosinase 활성 저해 및 항균활성 효과(5), 위암세포 증식 억제 및 연육효과 (6), 변비개선에 관한 연구(7) 등이 있다.

이렇게 건강 기능적인 면에서 여러 가지 장점을 지닌 과수이지만, 키위는 에틸렌 생성량의 증가, 과육의 연화, 유기산 감소 등 다양한 생리활성 현상이 진행되는 호흡 상승형 과실로 저장성이 낮고 장기 저장 시에 상품성이 떨어지는 단점을 가지고 있다(8). 따라서 키위를 활용한 다양한 형태의 키위 가공제품의 개발이 요구되고 있다. 유 산균 발효는 유산균에 의해 유용한 물질을 생산하고 항바이 러스, 항암, 항염증 및 항산화 등 건강상의 이점을 주는 전통 식품 발효법이며(9), 우유뿐만 아니라 과일을 유산균 을 이용해 발효하고, 저장성, 영양 품질 및 생리활성을 확인 하는 연구가 활발히 진행되고 있다. 이러한 연구로는 열대 과일 주스, 차의 유산균 발효에 따른 항산화 활성(10), 구아 바 추출물 유산균 발효(11) 등이 있다. 키위의 경우에는 주로 알코올 발효(12-15)와 초산 발효(16)에 관한 연구들이 보고되고 있는 반면, 유산균을 이용한 발효 및 유산균 발효 에 의한 키위의 항산화효능에 관한 연구는 보고된 바가 없어 이에 대한 연구가 필요하다.

생체 내에서 산화로 인해 발생하게 되는 활성산소종 (reactive oxygen species, ROS)은 과량 발생될 경우 DNA와 단백질을 불활성화 시키고, 세포 생체막의 구성 성분인 불 포화 지방산을 공격하여 생체기능을 저하시킨다. 이로 인 해 노화가 유발되며 암, 심장병과 같은 여러 질환의 원인이 된다. 항산화제(antioxidants)는 이러한 유해한 활성산소에 의해 발생되는 지질의 과산화, 세포막 및 적혈구 파괴, 발암 물질의 생성, 세포의 노화 등의 작용을 억제하며, 식품 보존 성 향상에도 이용된다. 현대 사회에서 건강 및 웰빙에 대한 소비자들의 관심이 증가함에 따라 생체 내 항산화 방어시스 템을 간접적으로 증가시키거나 직접적으로 활성산소종을 소거시키면서 인체에 부작용이 없는 항산화제 개발을 위한 연구가 활발히 진행되고 있다 $(17,18)$.

본 연구에서는 김치에서 유래한 Lactobacillus plantarum $\mathrm{CK} 10$ 을 이용하여 골드키위를 발효하고, 발효 기간 동안의 항산화 활성 변화에 대해 연구하였다. 이를 통해 항산화 활성이 증대된 발효 최적 조건 및 골드키위 발효 제품 개발 을 위한 기초자료를 제공하고자 하였다.

\section{재료 및 방법}

\section{실험재료 및 시약}

본 연구에서 재료로 사용한 제주산 한라골드 키위는 제 주 시내 마트에서 2016년 12월 중순 경에 구입하여 사용하
였다. Folin-Ciocalteu's reagent, Gallic acid, Rutin, 2,2-diphenyl1-picrylhydraxyl(DPPH), 2,2'-azino-bis-3-ethylbenzothiazoline6-sulfonic acid-diammonium salt(ABTS), pyrogallol, $\mathrm{FeCl}_{2}$, ferrozine은 Sigma Chemical Co.(St. Louis, MO, USA)에서 구입하여 사용하였으며, de Man, Rogosa and Sharpe(MRS) broth, peptone water는 BD Difco(Sparks, MD, USA)에서 구입하여 사용하였다.

\section{사용 균주 및 배양 조건}

실험에 사용한 균주는 오이소박이김치(Oisobak)로부터 유래한 Lactobacillus plantarum CK10으로 경기대학교 식품 생물공학과 이종훈 교수로부터 제공받아 사용하였다(19). L. plantarum CK10 균주는 MRS 배지를 이용하여 24시간 동안 $30^{\circ} \mathrm{C}, 100 \mathrm{rpm}$ 조건으로 배양하였다.

\section{골드키위 발효물 제조}

골드키위 배지는 Campanella 등(20)의 방법을 변형하여 수행하였다. 골드키위 파우더 5\%(v/v)와 peptone water $2 \%(\mathrm{v} / \mathrm{v})$ 를 증류수와 균질화한 후, $1 \mathrm{~N} \mathrm{NaOH}$ 를 이용하여 $\mathrm{pH} 6.00 \pm 0.50$ 으로 조정하였다. 그 후 autoclave를 이용하여 $121^{\circ} \mathrm{C}, 15$ 분 조건으로 멸균하였다. $L$, plantarum CK 10 은 접종 전 $\mathrm{MRS}$ 배지에서 2회 계대 배양하였으며, $600 \mathrm{~nm}$ 파장 에서 $\mathrm{OD}$ 값이 0.6 일 때 $(7.00 \pm 0.50 \log$ colony forming unit $(\mathrm{CFU}) / \mathrm{mL})$ 골드키위 배지에 $1 \%(\mathrm{v} / \mathrm{v})$ 접종하였다. 발효 는 $30^{\circ} \mathrm{C}, 100 \mathrm{rpm}$ 조건으로 7 일간 수행하였다.

\section{골드키위 발효 추출물 제조}

골드키위 발효물에 $80 \%$ ethanol(v/v) 조건이 되도록 ethanol을 가하고 sonicator로 15 분씩 3 회 반복 추출하였다. 각 추출물은 여과지로 여과한 후 rotary vacuum evaporator 로 $35^{\circ} \mathrm{C}$ 에서 감압 농축한 후 동결 건조하여 사용하였다. 발효하지 않은 골드키위 추출물도 동일한 방법으로 추출하 였다.

생균수, $\mathrm{pH}$, 산도 및 당도

생균수 측정은 시료 $100 \mu \mathrm{L}$ 를 phosphate buffer solution (PBS) $900 \mu \mathrm{L}$ 으로 균질화하여 희석하여 평판배양법으로 $\mathrm{MRS}$ 배지에 $100 \mu \mathrm{L}$ 씩 분주하고 $37^{\circ} \mathrm{C}, 2$ 일간 배양한 후 콜로 니를 계수하여 시료 $1 \mathrm{~mL}$ 당 $\mathrm{CFU}$ 으로 표시하였다. $\mathrm{pH}$ 는 Orion 3star benchtop pH meter(Thermo Scientific Inc. Waltham, MA, USA)를 이용하여 측정하였다. 총산도는 발 효물 $10 \mathrm{~mL}$ 에 $0.1 \mathrm{~N} \mathrm{NaOH}$ 를 이용하여 $\mathrm{pH} 8.2$ 가 될 때까지 적정하였으며 적정에 소비되는 $0.1 \mathrm{~N} \mathrm{NaOH}$ 의 소모량을 유기산 함량으로 환산하여 계산하였다. 총당도는 brix refractometer(PAL-1, Atago, Tokyo, Japan)을 이용하여 측정 하였다. 


\section{총 폴리페놀 함량}

총 폴리페놀 함량은 Cheung 등(21)의 방법을 약간 변형하 여 증류수 $1.375 \mathrm{~mL}$ 에 $125 \mu \mathrm{L}$ 의 시료를 넣은 후 $0.5 \mathrm{~mL}$ Folin-Ciocalteu's 시약을 넣고 4분 후에 $1 \mathrm{~mL}$ 의 $\mathrm{Na}_{2} \mathrm{CO}_{3}$ 를 가한 다음 상온에서 30 분 동안 정치하여 반응시켰다. 그 후 분광광도계(Sunrise, Tecan, Salzburg, Austria)를 이용하 여 $700 \mathrm{~nm}$ 에서 흡광도를 측정하였다. 함량은 $\mathrm{mg}$ gallic acid equivalents(GAE)/g dry weight로 나타내었다.

\section{총 플라보노이드 함량}

총 플라보노이드 함량은 Zhishen 등(22)의 방법을 변형하 여 측정하였다. 증류수 $80 \mu \mathrm{L}$ 에 시료 $40 \mu \mathrm{L}$ 를 넣은 후 $5 \%$ $\mathrm{NaNO}_{2} 6 \mu \mathrm{L}$ 를 첨가하여 5 분간 반응시킨 후 $10 \% \quad \mathrm{AlCl}_{3}$ $12 \mu \mathrm{L}$ 를 혼합하여 6분간 반응시킨 다음 $1 \mathrm{~N} \mathrm{NaOH} 40 \mu \mathrm{L}$ 를 첨가한다. 그 후 증류수 $42 \mu \mathrm{L}$ 를 넣고 앙금이 생기지 않도록 잘 섞어준 후 분광광도계(Sunrise, Tecan, Salzburg, Austria) 를 이용하여 $510 \mathrm{~nm}$ 에서 흡광도를 측정하였다. 함량은 $\mathrm{mg}$ rutin equivalents(RE)/g dry weight로 나타내었다.

\section{$\mathrm{Fe}^{2+}$ 이온 킬레이트 활성}

$\mathrm{Fe}^{2+}$ 이온 킬레이트 활성은 기존에 보고된 방법(23)을 변형 하여 수행하였다. 시료를 농도별로 $100 \mu \mathrm{L}$ 씩 분주하고 $\mathrm{FeCl}_{2}$ $20 \mu \mathrm{L}$, ferrozine $40 \mu \mathrm{L}$, ethanol $640 \mu \mathrm{L}$ 를 넣은 후 상온에서 10 분간 반응시킨다. 반응이 끝나면 분광광도계(Sunrise, Tecan, Salzburg, Austria)를 이용하여 $562 \mathrm{~nm}$ 에서 흡광도를 측정하였다. 양성대조군으로는 ethylenediaminetetraacetic $\operatorname{acid}(\mathrm{EDTA})$ 을 사용하였다.

\section{$\mathrm{DPPH}$ 라디칼 소거 활성}

$\mathrm{DPPH}$ 라디칼 소거 활성은 기존에 보고된 방법 $(24,25)$ 을 토대로 하여 수행하였다. DPPH 라디칼 용액은 $\mathrm{DPPH}$ 를 $200 \mu \mathrm{M}$ 로 에탄올에 용해시켜 준비하였고, 96-well plate에 시료를 농도별로 $40 \mu \mathrm{L}$ 씩 분주하고 $200 \mu \mathrm{M} \mathrm{DPPH}$ 라디칼 용액 $160 \mu \mathrm{L}$ 를 첨가한 후 30 분간 $37^{\circ} \mathrm{C}$ incubator에서 반응시 켰다. 반응이 끝나면 분광광도계(Sunrise, Tecan, Salzburg, Austria)를 이용하여 $517 \mathrm{~nm}$ 에서 흡광도를 측정하였다. 양 성대조군으로는 catechin을 사용하였다.

\section{ABTS 라디칼 소거 활성}

$\mathrm{ABTS}$ 라디칼 소거 활성은 기존에 보고된 방법(26)을 변형하여 수행하였으며, ABTS 라디칼 용액은 $7 \mathrm{mM} \mathrm{ABTS}$ 와 $2.45 \mathrm{mM} \mathrm{K}_{2} \mathrm{~S}_{2} \mathrm{O}_{8}$ 를 혼합해 20시간 동안 암소에 보관하여 준비하였으며, $\mathrm{OD}$ 값이 $0.700 \pm 0.005$ 에 도달하게 증류수로 희석하여 사용하였다. 큐벳에 $900 \mu \mathrm{L} \mathrm{ABTS}$ 라디칼 용액과 $100 \mu \mathrm{L}$ 시료를 혼합하여 실온에서 2 분간 반응시킨 후, 분광 광도계(UV1800, Shimadzu, Kyoto, Japan)를 이용하여 734 $\mathrm{nm}$ 에서 흡광도를 측정하였다. 양성대조군으로는 a-tocopherol 을 사용하였다.

\section{Superoxide dismutase(SOD) 유사 활성}

SOD 유사 활성은 Marklund 등(27)의 방법을 토대로 하여 수행하였다. 96-well plate에 시료를 농도별로 $50 \mu \mathrm{L}$ 씩 분주 하고 $\mathrm{pH}$ 8.5로 보정한 Tris- $\mathrm{HCl}$ 완충용액 (50 mM Tris+10 $\mathrm{mM}$ EDTA, $\mathrm{pH} 8.5$ ) $50 \mu \mathrm{L}$ 와 $7.2 \mathrm{mM}$ pyrogallol $50 \mu \mathrm{L}$ 를 첨가한 후 45 분간 $25^{\circ} \mathrm{C}$ 상온에서 반응시켰다. 반응이 끝나 면 분광광도계(Sunrise, Tecan, Salzburg, Austria)를 이용하 여 $492 \mathrm{~nm}$ 에서 흡광도를 측정하였다. 양성대조군으로는 ascorbic acid을 사용하였다.

\section{통계처리}

모든 실험은 3회 반복 수행하여 평균치와 표준편차로 나타내었으며, 실험군 간의 유의성 검증 및 상관성 분석은 SPSS(Statistical package for social sciences, SPSS Inc, Chicago, IL, USA) software(version 18.0)를 이용하여 실시 하였으며, 유의성 검증의 경우 ANOVA one way로 수행하 였다.

\section{결과 및 고찰}

생균수, $\mathrm{pH}$, 산도 및 당도

L. plantarum $\mathrm{CK} 10$ 을 이용하여 발효한 골드키위 발효산 물의 시간별 생균수, $\mathrm{pH}$, 산도 및 당도 변화는 Table 1과 같다. 골드키위의 발효 시간별 생균수는 접종직후 $6.89 \pm$ $0.67 \log \mathrm{CFU} / \mathrm{mL}$ 에서 1 일 이후 $10.26 \pm 0.43 \log \mathrm{CFU} / \mathrm{mL}$ 로 유의적으로 증가하였으며, 발효 3 일 차에서 $12.03 \pm 1.29 \mathrm{log}$ $\mathrm{CFU} / \mathrm{mL}$ 로 가장 높은 생균수를 나타났다. 발효 5일과 7일 차에는 생균수가 각각 $8.00 \pm 0.82$ 와 $3.83 \pm 0.31 \log \mathrm{CFU} / \mathrm{mL}$ 로, 발효가 진행됨에 따라 생균수가 감소하는 경향을 나타 났다. 또한, $\mathrm{pH}$ 는 접종직후 $\mathrm{pH} 5.85 \pm 0.10$ 에서 발효시간에 따라 $\mathrm{pH}$ 가 감소하였으며, 발효 7일 차에 $3.64 \pm 0.03$ 까지 감 소하는 경향을 보여, Sung과 Choi(28)의 연구에서 유산균의 대사 활동에 의해 유기산이 증가하며 이로 인해 $\mathrm{pH}$ 감소, 산도가 증가한다는 보고와 유사한 결과였다. 산도 역시 접 종 직후 $0.41 \pm 0.05 \%(\mathrm{v} / \mathrm{v})$ 에서 발효 7일 차에 $1.80 \pm 0.08 \%(\mathrm{v} / \mathrm{v})$ 까지 증가하는 것을 확인하였다. 당도의 경우 발효직후 $6.43 \pm 0.05{ }^{\circ} \mathrm{Brix}$ 에서 발효가 진행됨에 따라 감소하였으며, 발효 7일 차에 $5.80 \pm 0.08{ }^{\circ} \mathrm{Brix}$ 까지 감소하는 것을 확인하였 다. 이는 $\mathrm{Kim}$ 등(29)의 연구에서 발효시간이 경과함에 따라 땅콩나물 요구르트의 당도가 유의적으로 감소한다는 보고 와 일치하였으며, 이러한 당도의 변화는 유산균에 의해 당 이 분해되고 유기산이 생성되었기 때문으로 사료된다. 한 편, 골드키위의 발효산물의 생균수 변화는 이전 연구 
(30-32)에서 발효 24시간까지 증가한 이후 감소한 결과와 달리 발효 3 일까지 유산균이 계속적으로 증가하였다. 이와 같은 결과는 발효에 사용한 배지 조성의 차이에 기인한 것으로 보이며 본 연구에서 사용한 골드키위 배지에는 펩톤 수가 첨가되어 있어 이러한 차이를 유발한 것으로 보인다. 즉, 발효에 의해 발생한 유기산과 낮은 $\mathrm{pH}$, 높은 산도 등이 골드키위 배지에 첨가된 펩톤수에 의해 일정 부분 상쇄되었 거나, 혹은 펩톤수 첨가로 인해 질소원의 공급이 풍부해져 유산균이 더 안정적으로 증식할 수 있었을 것으로 사료된 다.

Table 1. Determination of viability, $\mathrm{pH}$ value, and chemical characteristics during gold kiwifruit fermentation with Lactobacillus plantarum CK10

\begin{tabular}{ccccc}
\hline $\begin{array}{c}\text { Fermentation time } \\
\text { (days) }\end{array}$ & $\begin{array}{c}\text { Viability } \\
(\text { Log CFU/mL) }\end{array}$ & pH value & $\begin{array}{c}\text { TTA }^{1)} \\
(\%)\end{array}$ & $\begin{array}{c}\text { TSS }^{2)} \\
\left({ }^{\circ} B r i x\right)\end{array}$ \\
\hline 0 & $6.89 \pm 0.67^{3)(2)}$ & $5.85 \pm 0.10^{\mathrm{a}}$ & $0.41 \pm 0.05^{\mathrm{a}}$ & $6.43 \pm 0.05^{\mathrm{a}}$ \\
1 & $10.26 \pm 0.43^{\mathrm{b}}$ & $3.96 \pm 0.01^{\mathrm{b}}$ & $1.21 \pm 0.18^{\mathrm{b}}$ & $6.08 \pm 0.05^{\mathrm{b}}$ \\
2 & $11.97 \pm 1.78^{\mathrm{b}}$ & $3.78 \pm 0.02^{\mathrm{c}}$ & $1.49 \pm 0.30^{\mathrm{c}}$ & $5.98 \pm 0.05^{\mathrm{bc}}$ \\
3 & $12.03 \pm 1.29^{\mathrm{b}}$ & $3.70 \pm 0.02^{\mathrm{d}}$ & $1.64 \pm 0.15^{\text {cd }}$ & $5.85 \pm 0.06^{\mathrm{c}}$ \\
5 & $8.00 \pm 0.82^{\mathrm{a}}$ & $3.64 \pm 0.03^{\mathrm{d}}$ & $1.79 \pm 0.07^{\mathrm{d}}$ & $5.80 \pm 0.08^{\mathrm{c}}$ \\
7 & $3.83 \pm 0.31^{\mathrm{c}}$ & $3.64 \pm 0.03^{\mathrm{d}}$ & $1.80 \pm 0.08^{\mathrm{d}}$ & $5.80 \pm 0.08^{\mathrm{c}}$ \\
\hline
\end{tabular}

${ }^{1)}$ TTA, total titratable acidity.

${ }^{2}$ TSS, total soluble solid.

${ }^{3)}$ Values are Mean \pm SD ( $\left.=3\right)$.

${ }^{4}$ Different letters represent significant differences among extracts by least significant difference (LSD) test at $\mathrm{p}<0.05$

\section{총 폴리페놀 및 플라보노이드 함량}

발효시간에 따른 골드키위 추출물의 총 폴리페놀 및 플 라보노이드 함량은 Table 2와 같다. 총 폴리페놀 함량은 골드키위 무발효군에서 $0.96 \pm 0.04 \mathrm{mg} \mathrm{GAE} / \mathrm{g}$ dry weight으 로 나타났으며, 발효시간에 따라 점차적으로 증가하여 발 효 5 일 차에는 $1.21 \pm 0.13 \mathrm{mg} \mathrm{GAE} / \mathrm{g}$ dry weight으로 약 1.3 배 증가하였다. 총 플라보노이드 함량의 경우 무발효군에서 $0.10 \pm 0.02 \mathrm{mg} \mathrm{RE} / \mathrm{g} \mathrm{dry}$ weight으로 나타났으며, 총 폴리페 놀 함량과 같이 발효시간에 따라 증가하여 발효 5 일 차에 $0.36 \pm 0.04 \mathrm{mg} \mathrm{RE} / \mathrm{g}$ dry weight으로 약 3.6배 증가하였다. Jo 등(33)연구와 Kweon 등(34)의 연구에서는 대추혼합물과 율피의 경우 발효에 따른 폴리페놀 함량의 변화가 크지 않았으며, 플라보노이드 함량이 감소한다고 보고하였으나 Lee 등(32)의 연구에서는 오디 유산균 발효물이 발효에 의 해 총 폴리페놀과 플라보노이드 함량이 증가한다고 보고한 바 있다. 본 연구에서는 발효가 진행됨에 따라 총 폴리페놀 과 플라보노이드 함량 증가하는 경향을 보여, Lee 등(32)의 연구에서 보고한 오디 유산균 발효물의 항산화 활성과 유사 한 결과였다. 이와 같이 발효에 의한 총 폴리페놀과 플라보 노이드 함량 증가는 발효에 의해 생성된 가수분해효소가 식물 세포벽 기질을 붕괴시켜 페놀 화합물 추출을 촉진시키
고 글리코실화된 형태를 활성형의 아글리콘으로 전환시켜 나타난 결과로 사료된다(35). 페놀 화합물은 식물계에서 널리 분포되어 있는 대사산물로 환원제, 수소 공여체 및 활성 산소 소거제 등 다양한 항산화 활성과 생리활성에 작용하게 된다. 이러한 활성은 분자 내 phenolic hydroxyl기 가 효소 단백질 등 거대 분자들과 결합하는 특성이 있기 때문이라고 알려져 있다. 즉 페놀 함량이 높을 경우 산화 억제 작용이 높은 것을 의미한다(36).

Table 2. Total bioactive compounds of fermented gold kiwifruit extracts

\begin{tabular}{ccc}
\hline $\begin{array}{c}\text { Fermentation time } \\
\text { (days) }\end{array}$ & $\begin{array}{c}\mathrm{TPC}^{1)} \\
\left(\mathrm{mg} \mathrm{GAE}^{3} / \mathrm{g} \text { dry weight }\right)\end{array}$ & $\begin{array}{c}\mathrm{TFC}^{2)} \\
\left(\mathrm{mg} \mathrm{RE}^{4} / \mathrm{g}^{2} \mathrm{dry} \text { weight }\right)\end{array}$ \\
\hline $\mathrm{NFG}^{5)}$ & $0.96 \pm 0.04^{6 \mathrm{a} 7)}$ & $0.10 \pm 0.02^{\mathrm{a}}$ \\
1 & $0.98 \pm 0.06^{\mathrm{a}}$ & $0.15 \pm 0.02^{\mathrm{b}}$ \\
2 & $1.09 \pm 0.08^{\mathrm{b}}$ & $0.20 \pm 0.01^{\mathrm{c}}$ \\
3 & $1.15 \pm 0.09^{\mathrm{bc}}$ & $0.24 \pm 0.01^{\mathrm{d}}$ \\
5 & $1.21 \pm 0.13^{\mathrm{c}}$ & $0.36 \pm 0.04^{\mathrm{e}}$ \\
7 & $1.19 \pm 0.10^{\mathrm{c}}$ & $0.30 \pm 0.03^{\mathrm{f}}$ \\
\hline
\end{tabular}

${ }^{1)} \mathrm{TPC}$, total phenol content.

${ }^{2)} \mathrm{TFC}$, total flavonoid content.

${ }^{3)} \mathrm{GAE}$, gallic acid equivalents.

${ }^{4} \mathrm{RE}$, rutin equivalents.

${ }^{5} \mathrm{NFG}$, non-fermented gold kiwifruit extract.

${ }^{6}$ Values are Mean $\pm \mathrm{SD}(\mathrm{n}=3)$.

${ }^{7}$ Different letters represent significant differences among extracts by least significant difference (LSD) test at $\mathrm{p}<0.05$.

\section{$\mathrm{Fe}^{2+}$ 이온 킬레이트 활성}

금속 이온 킬레이트 활성은 활성산소종의 생성 억제를 하여 세포의 산화적 손상을 막으며 지질 과산화 생성물을 생성하는 역할을 하는 전이 금속 농도를 낮춘다(37). 발효시 간에 따른 골드키위 추출물의 $\mathrm{Fe}^{2+}$ 이온 킬레이트 활성은 Fig 1 과 같다. 모든 추출물은 농도 $125,250,500 \mu \mathrm{g} / \mathrm{mL}$ 로 수행하였으며, 발효한 골드키위 추출물에서 무발효군 23.56-65.67\% 와 비교하여 약 8-20\%의 활성이 증가하였다. 또한, 발효 5일 차에서 $38.40-78.47 \%$ 로 가장 높은 $\mathrm{Fe}^{2+}$ 이온 킬레이트 활성을 보였다. 이는 Kwon 등(38)의 연구에서 총 폴리페놀과 플라보노이드 함량이 높게 나타난 시료에서 금속이온 킬레이트 활성이 증가되었다는 보고와 유사한 경향을 보였다.

\section{$\mathrm{DPPH}$ 라디칼 소거 활성}

자유 라디칼은 인체 내에서 지질, 단백질등과 결합하여 노화를 일으키며, 항산화제의 경우 자유 라디칼을 상쇄, 환원하여 자유 라디칼을 소거한다고 알려져 있다(39). 많은 연구에서 DPPH 라디칼의 색 변화를 이용하여 항산화 활성 을 평가하는 지표로 활용하고 있다(40). 발효시간에 따른 골드키위 추출물의 DPPH 라디칼 소거 활성은 Fig. 2 와 같 


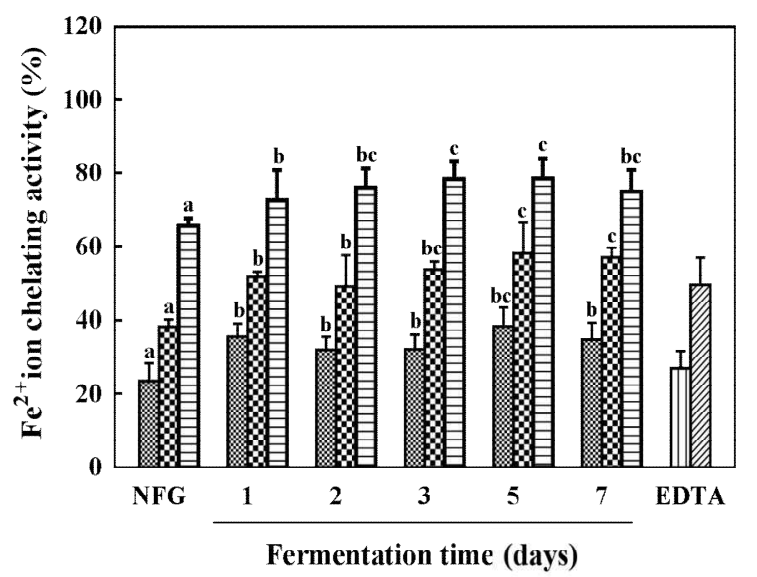

Fig. 1. $\mathrm{Fe}^{2+}$ ion chelating activity of fermented gold kiwifruit extracts.

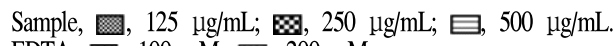

EDTA, 四, $100 \mu \mathrm{M}$; 四, $200 \mu \mathrm{M}$.

NFG, non-fermented gold kiwifruit extract.

The appropriate amount of EDTA was used as a positive control

Values are Mean $\pm S D(n=3)$. Different letters represent significant differences among extracts by LSD test at $\mathrm{p}<0.05$.

다. 모든 추출물은 농도 $2.5,5,10 \mathrm{mg} / \mathrm{mL}$ 로 수행하였으며, 무발효군 19.04-74.52\%와 비교하여 발효시간에 따라 $\mathrm{DPPH}$ 라디칼 소거 활성이 증가하였다. 발효 7일 차에서 36.01- 86.81\%로 가장 높은 DPPH 라디칼 소거 활성을 보였 다. 이는 Song 등(41)의 연구에서 유산균 발효에 의해 톳의 $\mathrm{DPPH}$ 라디칼 소거 활성이 증가한다는 보고와 Lee 등(32)의 연구에서 유산균 발효에 의해 오디의 $\mathrm{DPPH}$ 라디칼 소거 활성이 5-11\% 증가한다는 보고와 유사한 결과였다. 이러한 결과는 유산균 발효에 의해 생산된 페놀 화합물과 같은 대사 산물이 DPPH 라디칼 소거 활성에 기여한 것으로 사료된다.

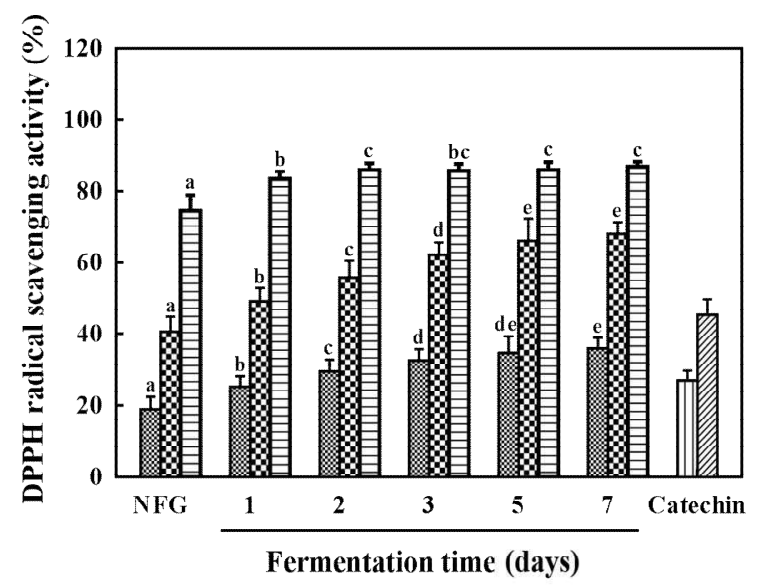

Fig. 2. DPPH radical scavenging activity of fermented gold kiwifruit extracts.

Sample, 四, $2.5 \mathrm{mg} / \mathrm{mL} ; \otimes, 5 \mathrm{mg} / \mathrm{mL} ;$ 曰, $10 \mathrm{mg} / \mathrm{mL}$.

Catechin, 四, $100 \mu \mathrm{M} ;$ 向, $200 \mu \mathrm{M}$.

NFG, non-fermented gold kiwifruit extract

The appropriate amount of catechin was used as a positive control.

Values are Mean $\pm S D(n=3)$. Different letters represent significant differences among extracts by LSD test at $\mathrm{p}<0.05$.

\section{ABTS 라디칼 소거 활성}

$\mathrm{ABTS}$ 라디칼은 청록색의 ABTS 라디칼이 항산화제와 만나면 하늘색으로 탈색되는 특징을 이용한 실험으로 hydrogen-donating antioxidants와 chain breaking antioxidants 를 모두 측정할 수 있으며, aqueous phase와 organic phase 모두 적용 가능하다(42). 발효시간에 따른 골드키위 추출물 의 $\mathrm{ABTS}$ 라디칼 소거 활성은 Fig. 3 과 같다. 모든 추출물은 농도 $1.25,2.5,5 \mathrm{mg} / \mathrm{mL}$ 로 수행하였으며, 발효 5 일 차 19.76-70.88\%를 제외한 모든 발효 추출물에 무발효군 $18.08-64.30 \%$ 과 유의한 ABTS 라디칼 소거 활성을 보였다. 여러 연구자들의 $\mathrm{DPPH}$ 라디칼 소거 활성과 $\mathrm{ABTS}$ 라디칼 소거 활성이 높은 상관관계를 보인다는 보고(43)와 다른 결과를 보였으나, 이는 DPPH 라디칼 소거 활성과 ABTS 라디칼 소거 활성은 각각 자유 라디칼과 양이온 라디칼을 소거하고 각각 기질에 결합하는 정도의 차이가 있기 때문에 다른 경향을 보인 것으로 사료된다.

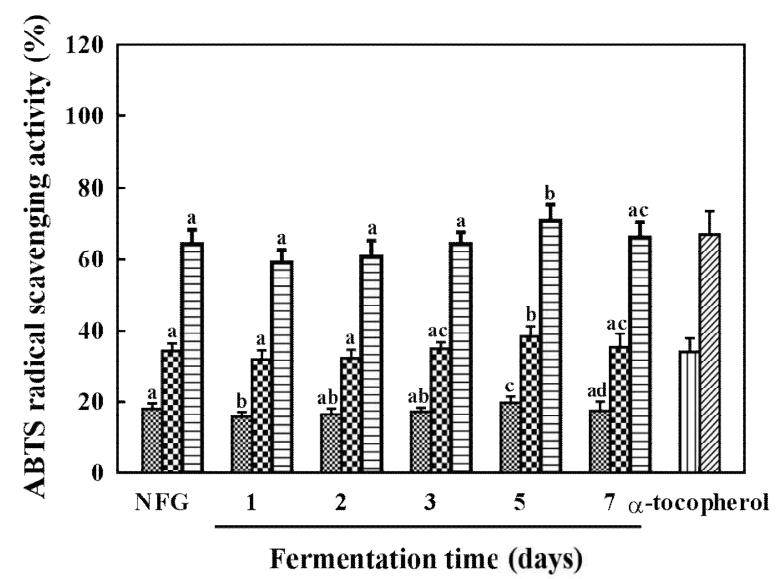

Fig. 3. ABTS radical scavenging activity of fermented gold kiwifruit extracts.

Sample, 圆, $1.25 \mathrm{mg} / \mathrm{mL} ; \mathbb{*}, 2.5 \mathrm{mg} / \mathrm{mL} ;$ 曰日, $5 \mathrm{mg} / \mathrm{mL}$.

a-tocopherol, 四, $100 \mu \mathrm{M} ;$ घ, $200 \mu \mathrm{M}$.

NFG, non-fermented gold kiwifruit extract.

The appropriate amount of a-tocopherol was used as a positive control.

Values are Mean $\pm \mathrm{SD}(\mathrm{n}=3)$. Different letters represent significant differences among extracts by LSD test at $\mathrm{p}<0.05$.

\section{$S O D$ 유사 활성}

$\mathrm{SOD}$ 는 생체 내 항산화 효소 중 하나로 세포 내 활성산소 를 과산화수소로 전환시키는 반응을 촉매하는 효소이다. $\mathrm{SOD}$ 에 의해 생성된 과산화수소는 catalase와 같은 효소에 의해 무해한 물과 산소분자로 전환된다(44). SOD 유사 활 성은 효소는 아니지만 주로 phytochemical과 같은 저분자 물질이 SOD와 유사한 역할을 하여 인체 내의 superoxide를 제거함으로써 산화적 스트레스를 방어하는 효과를 갖는다 (45). 발효시간에 따른 골드키위 추출물의 SOD 유사 활성 은 Fig. 4와 같다. 모든 추출물은 농도 $2.5,5,10 \mathrm{mg} / \mathrm{mL}$ 로 수행하였으며, 무발효군 10.33-36.00\%와 비교하여 발효시 간에 따라 점차적으로 증가하였으며 발효 7일 차에 54.79- 
93.83\%로 무발효군과 비교하여 약 $44-57 \%$ 증가하는 것을 확인하였다. 이는 Hur 등(35)의 연구에서 유산균 발효 과정 에서 SOD 및 catalase가 형성되어 항산화 활성이 증가한다 는 보고와 유사했으며, Jeon 등(46)의 연구에서 DPPH 라디 칼 소거 활성이 높은 시료에서 SOD 유사 활성이 높았다는 보고와 유사한 결과였다. 또한, SOD 유사 활성이 유산균 발효에 의해 두드러지게 증가하였는데 이는 다른 라디칼과 비교하여 발효한 골드키위 추출물이 superoxide 라디칼을 효과적으로 소거할 수 있음을 시사한다.

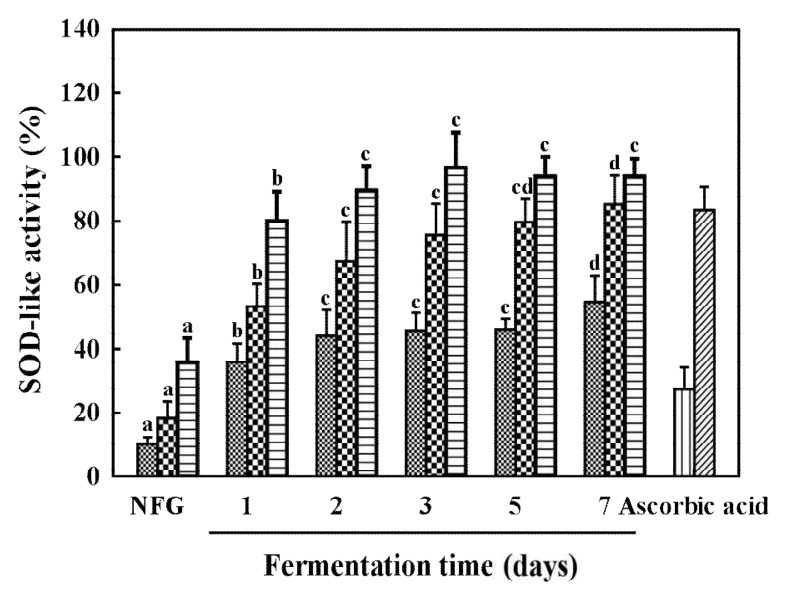

Fig. 4. SOD-like activity of fermented gold kiwifruit extracts.

Sample, 圆, $2.5 \mathrm{mg} / \mathrm{mL} ; \otimes, 5 \mathrm{mg} / \mathrm{mL}$; 目, $10 \mathrm{mg} / \mathrm{mL}$.

Ascorbic acid, 四, $25 \mu \mathrm{g} / \mathrm{mL} ;$ 四, $50 \mu \mathrm{g} / \mathrm{mL}$.

NFG, non-fermented gold kiwifruit extract.

The appropriate amount of ascorbic acid was used as a positive control

Values are Mean $\pm \mathrm{SD}(\mathrm{n}=3)$. Different letters represent significant differences among extracts by LSD test at $\mathrm{p}<0.05$.

\section{상관관계 분석}

발효시간에 따른 골드키위 추출물의 항산화 물질과 항산 화 활성간의 상관성을 비교한 결과는 Table 3 과 같다. 총 폴리페놀 함량과 총 플라보노이드, $\mathrm{Fe}^{2+}$ 이온 킬레이트 활성, $\mathrm{DPPH}$ 및 $\mathrm{ABTS}$ 라디칼 소거 활성 그리고 SOD 유사 활성 간의 상관계수 $0.962(\mathrm{p}<0.01), 0.830(\mathrm{p}<0.05), 0.973(\mathrm{p}<0.01)$, $0.709,0.900(\mathrm{p}<0.05)$ 으로 높은 양의 상관관계를 보였다. 총 플라보노이드 함량과 $\mathrm{Fe}^{2+}$ 이온 킬레이트 활성, $\mathrm{DPPH}$ 및 $\mathrm{ABTS}$ 라디칼 소거 활성 그리고 SOD 유사 활성 간의 상관 계수는 0.879(p<0.05), 0.944(p<0.01), 0.771, 0.871( $<<0.05)$ 로 양의 상관관계를 보였다. 그리고 $\mathrm{Fe}^{2+}$ 이온 킬레이트 활성 과 DPPH, ABTS 라디칼 소거 활성 및 SOD 유사 활성간의 상관계수는 $0.918(\mathrm{p}<0.01), 0.459,0.945(\mathrm{p}<0.01)$ 로 $\mathrm{ABTS}$ 라 디칼 소거 활성을 제외한 항산화 활성에서 높은 양의 상관 관계를 보였다. DPPH 라디칼과 $\mathrm{ABTS}$ 라디칼 소거 활성, SOD 유사 활성은 $0.588,0.967(\mathrm{p}<0.01)$ 로 $\mathrm{DPPH}$ 라디칼과 $\mathrm{SOD}$ 유사 활성의 경우 유의적으로 높은 양의 상관관계를 보였으며, ABTS 라디칼 소거 활성과 SOD 유사 활성은 0.389 으로 다소 낮은 상관관계를 보였다. 이는 Jeon 등(46)
의 연구에서 폴리페놀 함량이 높을수록 플라보노이드 함 량, DPPH 라디칼 소거활성이 높은 상관관계를 보인다는 보고와 유사한 결과였으며, $\mathrm{Kim}$ 등(47)의 연구에서 폴리페 놀 함량과 superoxide 라디칼 소거 활성과 양의 상관관계를 보인다는 결과와도 유사하였다.

Table 3. Pearson's correlation coefficients of phytochemical concentration and antioxidant activities of fermented gold kiwifruit extracts

\begin{tabular}{ccccccc}
\hline & $\mathrm{TPC}^{1)}$ & $\mathrm{TFC}^{2)}$ & $\mathrm{Fe}^{2+3)}$ & $\mathrm{DPPH}^{4)}$ & $\mathrm{ABTS}^{5)}$ & $\mathrm{SOD}^{6}$ \\
\hline $\mathrm{TPC}$ & 1 & - & - & - & - & - \\
$\mathrm{TFC}$ & $0.962^{* * 7}$ & 1 & - & - & - & - \\
$\mathrm{Fe}^{2+}$ & $0.830^{*}$ & $0.879^{*}$ & 1 & - & - & - \\
$\mathrm{DPPH}$ & $0.973^{* *}$ & $0.944^{* *}$ & $0.918^{* *}$ & 1 & - & - \\
$\mathrm{ABTS}$ & 0.709 & 0.771 & 0.459 & 0.588 & 1 & - \\
$\mathrm{SOD}$ & $0.900^{*}$ & $0.871^{*}$ & $0.945^{* *}$ & $0.967^{* *}$ & 0.389 & 1 \\
\hline
\end{tabular}

${ }^{1)} \mathrm{TPC}$, total polyphenol content.

${ }^{2}$ TFC, total flavonoid content.

${ }^{3)} \mathrm{Fe}^{2+}, \mathrm{Fe}^{2+}$ ion chelating activity.

${ }^{4} \mathrm{DPPH}, \mathrm{DPPH}$ radical scavenging activity.

${ }^{5}$ ABTS, ABTS radical scavenging activity.

${ }^{6}$ SOD, SOD-like activity.

${ }^{7}$ Correlation is significant at ${ }^{*}, \mathrm{p}<0.05 ;{ }^{* *}, \mathrm{p}<0.01$.

\section{요 약}

김치에서 유래한 Lactobacillus plantarum CK10을 이용 하여 골드키위를 발효하고, 발효 시간대별 각 발효산물을 에탄올로 추출한 후, 추출물에 대한 이화학적 특성 및 항산 화 활성을 측정하였다. 생균수는 발효 3 일 차에서 가장 높은 $12.03 \pm 1.29 \log \mathrm{CFU} / \mathrm{mL}$ 을 나타냈으며 시간이 지남에 따라 점차 감소하였다. $\mathrm{pH}$ 및 산도는 발효 7일 차에서 각각 감소 $(\mathrm{pH} 3.64 \pm 0.03)$ 및 증가 $(1.80 \pm 0.08 \%(\mathrm{v} / \mathrm{v}))$ 하였다. 당도는 무 발효군 $6.43 \pm 0.05{ }^{\circ} \mathrm{Brix}$ 에서 발효에 의해 감소하여 발효 7 일 차에서 $5.80 \pm 0.08{ }^{\circ} \mathrm{Brix}$ 로 가장 낮게 나타났다. 총 폴리 페놀과 플라보노이드 함량은 발효 5 일 차에서 각각 $1.21 \pm 0.13 \mathrm{mg} \mathrm{GAE} / \mathrm{g}$ dry weight, $0.36 \pm 0.04 \mathrm{mg} \mathrm{RE} / \mathrm{g}$ dry weight로 무발효군에 비해 높게 나타났으며, $\mathrm{Fe}^{2+}$ 이온 킬레 이트 활성에서 역시 발효 5일 차에서 38.40-78.47\%로 무발 효군과 비교하여 높은 활성이 나타났다. DPPH 라디칼 소거 활성 및 SOD 유사활성은 발효 7일 차에서 각각 36.01$86.81 \%, 54.79-93.83 \%$ 로 무발효군과 비교하여 높은 활성을 보였으며, ABTS 라디칼 소거 활성은 무발효군과 비교하여 약간 증가하거나 유사한 소거 활성을 보였다. 또한, 발효 5-7일에서 항산화 물질의 함량 증가와 항산화 활성이 증가 하는 것을 확인하였다. 따라서 향후 항산화 활성이 증가한 골드키위 유산균 발효물을 기능성 식품 개발에 적용 가능할 것으로 사료된다. 


\section{감사의 글}

이 논문은 2016년도 정부(교육부)의 재원으로 한국연구 재단의 지원을 받아 수행된 기초연구사업(2016R1A6A1A03012862) 과 산업통상자원부와 한국산업기술진흥원의 2017년 지역 주력 산업육성(R\&D)의 연구결과입니다.

\section{References}

1. Jeong CH, Lee WJ, Bae SH, Choi SG (2007) Chemical components and antioxidative activity of Korean gold kiwifruit. J Korean Soc Food Sci Nutr, 36, 859-865

2. Oh HJ, Jeon SB, Kang HY, Yang YJ, Kim SC, Lim SB (2011) Chemical composition and antioxidative activity of kiwifruit in different cultivars and maturity. J Korean Soc Food Sci Nutr, 40, 343-349

3. Kim SC, Song EY, Kim CH (2012) A new kiwifruit variety, 'halla gold' with high soluble solids content and early harvesting. Korean J Hortic Sci Technol, 30, 334-337

4. Lee II, Lee BH, Eom SH, Oh CS, Kang H, Cho YS, Kim DO (2015) Antioxidant capacity and protective effects on neuronal PC-12 cells of domestic bred kiwifruit. Korean J Hortic Sci Technol, 33, 259-267

5. Heo BG, Park YJ, Kim TC, Park YS, Cha WM, Kim HJ, Ahn JS, Baek SH, Park SM (2009) Tyrosinase inhibition and anti-microbial activities of kiwifruits extract. J Life Sci Nat Res, 32, 107-119

6. Heo BG, Park YS, Park YJ, Jang HG, Choi JR, Cho JY (2010) Hyperplasia inhibition activity of classified kiwifruits against gastric cancer cells and its meat softening activity. J Life Sci Nat Res, 32, 25-36

7. Kim DG, Jin YG, Jin JY, Kim SC, Kim SC, Han CH, Lee YJ (2011) Effects of the Actindia chinensis on loperamide-induced constipation in rat. Korean J Plant Res, 24, 61-68

8. Lee HY, Seo WT, Jeong SH, Hwang CE, Ahn MJ, Lee AR, Shin JH, Lee JY, Jo HK, Cho KM (2016) Physicochemical characteristics and volatile flavor compounds of produced mixture wine with kiwi and permission fruits using wild yeast, Saccharomyces cerevisiae Y28. Korean J Microbiol, 52, 98-109

9. Parvez S, Malik KA, Kang SA, Kim HY (2006) Probiotics and their fermented food products are beneficial for health. J Appl Microbiol, 100, 1171-1185

10. Fessard A, Kapoor A, Patche J, Assemat S, Hoarau M,
Bahorun T, Remize F (2017) Lactic fermentation as an efficient tool to enhance the antioxidant activity of tropical fruit juices and teas. Microorganisms, 5, 1-20

11. Bhat R, Suryanarayana LC, Chandrashekara KA, Krishnan P, Kush A, Ravikumar P (2015) Lactobacillus plantarum mediated fermentation of Psidium guajava L. fruit extract. J Biosci Bioeng, 119, 430-432

12. Woo SM, Choi IW, Jeong YJ (2006) Effect of kiwi wine and kiwi liqueur on sensory characteristics as cooking alcohol. Korean J Food Preserv, 13, 519-523

13. Woo SM, Lee MH, Seo JH, Kim YS, Choi HD, Choi IW, Jeong YJ (2007) Quality characteristics of kiwi wine on alcohol fermentation strains. J Korean Soc Food Sci Nutr, 36, 800-806

14. Kang SD, Ko YJ, Kim EJ, Son YH, Kim JY, Seol HG, Kim IJ, Cho HK, Ryu CH (2011) Quality characteristics of kiwi wine and optimum malolactic fermentation conditions. J Life Sci, 21, 509-514

15. Oh HJ, Lim SB (2017) Quality changes in kiwifruit wines during fermentation and aging with different yeasts. J Korean Soc Food Sci Nutr, 46, 481-489

16. Woo SM, Kim OM, Choi IW, Kim YS, Choi HD, Jeong YJ (2007) Condition of acetic acid fermentation and effect of oligosaccharide addition on kiwi vinegar. Korean $\mathbf{J}$ Food Preserv, 14, 100-104

17. Yu MH, Chae IG, Jung YT, Jeong YS, Kim HI, Lee IS (2011) Antioxidative and antimicrobial activities of methanol extract from Rosmarinus offcinalis L. and their fractions. J Life Sci, 21, 375-384

18. Chae IG, Kim HJ, Yu MH, Kim HI, Lee IS (2010) Antioxidant and antibacterial activity of commercially available herbs in Korean markets. J Korean Soc Food Sci Nutr, 39, 1411-1417

19. Kwon TY, Shim SM, Lee JH (2008) Characterization of lactobacilli with tannase activity isolated from Kimchi. Food Sci Biotechnol, 17, 1322-1326

20. Campanella D, Rizzello CG, Fasciano C, Gambacorta G, Pinto D, Marzani B, Scarano N, Angelis MD, Gobbetti $M$ (2017) Exploitation of grape marc as functional substrate for lactic acid bacteria and bifidobacteria growth and enhanced antioxidant activity. Food Microbiol, 65, 25-35

21. Cheung LM, Cheung PCK, Ooi VEC (2003) Antioxidant activity and total phenolics of edible mushroom extracts. Food Chem, 81, 249-255

22. Zhishen J, Mengcheng T, Jianming W (1999) The determination of flavonoid contents in mulberry and their 
scavenging effects on superoxide radicals. Food Chem, 64, 555-559

23. Gulcin I (2006) Antioxidant activity of caffeic acid (3,4-dihydroxycinnamic acid). Toxicol, 217, 213-220

24. Blois MS (1958) Antioxidant determinations by the use of a stable free radical. Nature, 181, 1199-1200

25. Brand-Williams W, Cuvelier ME, Berset C (1995) Use of a free radical method to evaluate antioxidant activity. LWT-Food Sci Technol, 28, 25-30

26. Re R, Pellegrini N, Proteggente A, Pannala A, Yang M, Rice-Evans C (1999) Antioxidant activity applying an improved ABTS radical cation decolorization assay. Free Radical Biol Med, 26, 1231-1237

27. Marklund S, Marklund G (1974) Involvement of superoxide anion radical in the oxidation of pyrogallol and a convenient assay for superoxide dismutase. Eur J Biochem, 47, 468-474

28. Sung JM, Choi HY (2014) Effect of mulberry powder on antioxidant activities and quality characteristics of yogurt. J Korean Soc Food Sci Nutr, 43, 690-697

29. Kim JY, Kwon SJ, Kang HI, Lee JH, Kang JS, Seo KI (2013) Quality characteristics and antioxidant effects of peanut sprout soybean yogurt. Korean J Food Preserv, 20, 199-206

30. Yang SJ, Hong JH (2015) Quality characteristics of Yanggaeng prepared with fermented blueberry by lactic acid bacteria. Korean J Food Cook Sci, 31, 128-135

31. Ahn CS, Yuh CS, Bang IS (2009) Physicochemical characteristics of fermented milk containing mulberry leaf extract. Korean J Food Nutr, 22, 272-278

32. Lee DH, Hong JH (2016) Physicochemical properties and antioxidant activities of fermented mulberry by lactic Acid Bacteria. J Korean Soc Food Sci Nutr, 45, 202-208

33. Jo HE, Chong MS, Choi YH (2010) Evaluation of composition and antioxidant activity from Zizyphus jujuba fruits and leaves extracts for development medicinal food. Korean J Orient Med Physiol Pathol, 24, 859-865

34. Choi MO, Kim BJ, Jo SK, Jung HK, Lee JT, Kim HY, Kweon DJ (2013) Anti-allergic activities of Castanea crenata inner shell extracts fermented by Lactobacillus bifermentans. Korean J Food Preserv, 20, 583-591

35. Hur SJ, Lee SY, Kim YC, Choi IW, Kim GB (2014) Effect of fermentation on the antioxidant activity in plant-based foods. Food chem, 160, 346-356

36. Gu YR, Kim SW, Son YW, Hong JH (2017) Antioxidant activities of solvent extracts from different Glehnia Radix parts and their inhibitory effect against nitric oxide production in Raw 264.7 cell. Korean J Food Preserv, 24, 116-124

37. Kang MY, Lee SH, Lee SW, Cha SW, Son JL, Lee SC (2015) Effect of achyranthis radix and drynariae rhizoma extracts on antioxidant activity and antioxidant enzymes. Korean J Plant Res, 28, 600-607

38. Kwon YR, Youn KS (2014) Antioxidant activity and physiological properties of Moringa(Moringa oleifera Lam.) leaves extracts with different solvents. Korean J Food Preserv, 21, 831-837

39. Shin DS, Han GJ (2016) Chemical compositions and antioxidant activities of Cheonnyuncho (Opuntia humifusa) stems and fruit. Korean J Food Preserv, 23, 89-96

40. Kang HR, Koh SY, Ryu JY, Osman A, Lee CK, Lim JH, Kim HA, Im GH, Kim SM (2016) Antioxidant activities and physicochemical properties of chocolate fermented by Lactobacillus plantarum CK10. Korean J Food Preserv, 23, 576-584

41. Song HS, Eom SH, Kang YM, Choi JD, Kim YM (2011) Enhancement of the antioxidant and anti-inflammatory activity of Hizikia fusiforme water extract by lactic acid bacteria fermentation. Korean J Fish Aquat Sci, 44, 111-117

42. Lee CY, Kim KM, Son HS (2013) Optimal extraction conditions to produce rosemary extracts with higher phenolic content and antioxidant activity. Korean J Food Sci Technol, 45, 501-507

43. Cho YJ, Kim JH, Yoon SJ, Chun SS, Choi UK (2005) Studies on the biological activity of Rosemarinus officinalis L. Korean J Food Sci Technol, 37, 970-975

44. Kim DH, Park SR, Debnath T, Hasnat AH, Pervin M, Lim BO (2016) Evaluation of the antioxidant activity and anti-inflammatory effect of Hericium erinaceus Water Extracts. Korean J Med Crop Sci, 21, 112-117

45. Jeon GI, Kim JM, Park EJ (2011) Comparison of antioxidant and antiproliferative activities of paprika (Capsicum annuum L.) with different skin colors. Cancer Prev Res, 16, 180-188

46. Jeon SM, Kim SY, Kim IH, Go JS, Kim HR, Jeong JY, Lee HY, Park DS (2013) Antioxidant activities of processed deoduck (Codonopsis lanceolata) Extracts. J Korean Soc Food Sci Nutr, 42, 924-932

47. Kim EY, Baik IH, Kim JH, Kim SR, Rhyu MR (2004) Screening of the antioxidant activity of some medicinal plants. Korean J Food Sci Technol, 36, 333-338 